\title{
Felnőttkori tanulási motivációk feltárása különböző képzési szinteken
}

\section{Explore adult learning motivations of various training levels}

\author{
A. PIEROG \\ Debreceni Egyetem, Gazdaságtudományi Kar, Vezetés- és Szervezéstudományi Intézet, \\ pierog.anita@econ.unideb.hu
}

Absztrakt. Mindennapjaink része a folyamatos tanulás. Ez lehet formális, non-formális vagy informális jellegü is. A formális tanulás, mely az iskolapadban történik, adja a szaktudás alapját. Hogy valaki miért ül iskolapadba? Erre a kérdésre számtalan válasz adható. A tanulás motivációja belső és külső tényezők hatására egyaránt kialakul(hat). Sőt akár korosztályonként, képzési formánként eltérhet. A felnöttkori tanulás motivációjának vizsgálatával kapcsolatban több felmérés készült. Ennek megfelelöen ezen vizsgálati eredmények egy-egy elemének összefoglalására vállalkozom ebben a cikkben. Egyrészrôl a középiskolások, másrészrôl a levelező képzésben egyetemi mesterszakon tanulók, valamint egy OKJ képzésben résztvevő csoport körében végzett felmérés eredményeit mutatom be. A felmérések célja az volt, hogy meghatározhassuk, az egyes képzési formában miért tanulnak az egyének. Annak ellenére, hogy a kérdésfeltevés a különböző vizsgálatokban némileg eltért egymástól, a tényezők ettől összehasonlíthatóak. Az OKJ képzésben résztvevők számára a habituális motiváció a döntó. Esetükben a fontosságot illetően a saját öröm és a család büszkesége némileg elmarad. A levelezô mesterszakosok esetében a jövedelem, maga a tanulás és a tájékozottság a legfontosabb. Ennek megfelelően, bár korcsoportonként a megítélés más, mégis vegyesen jelentkezik a habituális és az aktuális motiváció. Míg középiskolások eredményei alapján elmondható, hogy a motivációjuk inkább a végcél elérése, munkahely, jövedelem megszerzése a cél, így egyértelmüen a habituális motiváció a kiemelkedő. Ami mindenképpen kiemelendô a középiskolások esetében, hogy különbséget tettek a baráti kapcsolatok és a kapcsolati háló között. Azaz a barátságot nem azonosítják a pusztán ismeretséggel, melyet a jövőbeli célok eléréséhez tarthatnak szükségesnek

Abstract. Continuous learning is part of everyday life. It may be formal, non-formal or informal nature. The formal learning that takes place at school, is the basis of expertise. Why someone sitting to school? There can be given many answers to this question. The motivation for learning develops due to both internal and external factors. And even age groups and training as equally different. With regard to adult learning motivation was examining several surveys. The study is a summary of the test results. There was three target group: high school seniors, correspondence master's students and participants accredited training. The surveys set out to discover Why learn the various forms of training. The questions in each test were different but comparable. For participants accredited training habitual motivation is crucial. Their joy and pride of the family is less important to them. , Correspondence master's students were considered the most important things income, learning, and knowledge. Although the perception of other age groups, both the habitual and the actual motivation appears in every group. While high 
school students based on the results we can say that the more motivation to achieve a goal, such as employment, income acquire. so prominent the habitual motivation. In their case it emphasized that a distinction was made between friendship and relationship network. Namely, the friendships are not identified with the mere knowledge that may be necessary in order to achieve future goals.

\section{Bevezetés}

Napjainkban a XXI. század meghatározó eleme a folyamatos, egész életen át tartó tanulás. Az Európai Unió, és ezzel együtt Magyarország is nagy figyelmet fordít arra, hogy a képzett, szakképzett lakosság számát a következő években megnövelje. Emellett a munkaadók, illetve a munkaerőpiac megköveteli a szakismeretek folyamatos frissítését. Miután tudástársadalomban élünk, a technológia folyamatosan és igen gyors ütemben fejlődik, a humán-tőke fejlesztése, és a tudás egyre magasabb szintre hozása elengedhetetlen. Ez a törekvés természetesen nem valósulhat meg az érintettek nélkül, anélkül, hogy az emberek ne akarnának tanulni, képzettséget, új ismereteket szerezni. A formális tanulás ebben az aspektusban nem merül ki a felsőoktatási intézményekben történő képzésekre. A továbbtanulás egyaránt jelenti ezen túlmenően a különböző szakképzéseket, tanfolyamokat is. Az elmúlt években több vizsgálatot folytattunk a hallgatókkal arra vonatkozóan, hogy különböző képzési szinten tanuló emberek miért vesznek részt abban az oktatásban. A vizsgálatok célcsoportja minden esetben eltérő korosztályba is tartoznak, így az eredmények lehetőséget biztosítanak, hogy megnézzük van-e eltérés az egyes generációk továbbtanulási motivációjában. A témával kapcsolatos alapfeltevésem az, hogy a középiskola után teljesen más okokat jelölnek meg a fiatalok arra vonatkozóan, hogy miért mennek tovább bármilyen képzésbe, mint azok, akik felnőttként munka mellett vállalják a továbbtanulást.

\section{Szakirodalmi áttekintés}

A mai munkaerő-piaci érdek vezérelte társadalmunkban örökérvényű, hogy egyre több egyén tölt egyre több időt új ismeretek, és készségek megszerzésével. A permanens, egész életen át tartó tanulás meghatározóvá vált, és létrejött az úgynevezett tudás társadalom. Emellett a szerzők szerint hidat is jelenthet a felsőoktatás világa, a felsőoktatás rendszere és a munkaerő-piac között [26]. A lifelong learning a mai kor, és a jövő társadalmának irányadó jelensége [8]. A munkaerőpiac a munkavállalóktól nap, mint nap magasabb képesítést követel meg, ennek következtében jelentős nagyságúra nőtt azon alkalmazottak száma, akik át - vagy továbbképzik magukat a pályafutásuk során. A képzésekre, és a megszerzett tudásra részben a szakmai fennmaradás ösztönöz, részben az individuális kíváncsiság, és nyitottság az újdonság felé [29].

Az egész életen át tartó tanulással társadalmi kérdésként foglalkozik illetve foglalkozott az Európai Bizottság is. A Bizottság 2000-ben nyilvánosságra hozott egy Memorandumot, amelyben az életen át tartó tanulásra vonatkozóan kulcsfontosságú stratégiákat határoztak meg az alábbiak szerint:

- egyetemes, folyamatos hozzáférés a tanuláshoz a tagországokban

- humán erőforrásokba történő beruházások növelése

- a tanulásban való részvétel fontosságának a hangsúlyozása 
- a tanulási lehetőségekkel kapcsolatos információk elérhetővé tétele

- az élethosszig tartó tanulás lehetőségének a megteremtése az infokommunikációs technológiák és eszközök alkalmazásával.

\subsection{Tanulás meghatározása}

„A tanulás mindenki számára ismerős fogalom, amely hétköznapjaink, életünk szerves részét képezi. A legáltalánosabb és egyben a legbonyolultabb emberi tevékenység. Általános, hiszen mindenki mindig és mindenhol tanul, ugyanakkor bonyolult, mert az egész személyiségünk aktivitását igényli, és az egész személyiségünkre kihat" [28]. A tanulás vizsgálatával elsőként a behaviorista iskola foglalkozott, melyet viselkedésként, észlelő folyamatként határoztak meg. A tanulásra számos tényező hat, ezért a pszichológia igyekszik az összes lehetséges dimenziót feltárni, mely befolyásolhatja azt. A leggyakoribb értelmezés szerint olyan mentális folyamat, melynek következménye a tanulás eredménye, illetve a tanulóban végbemenő változások, a megtanultakat fedi le [9]. Egy másik meghatározás szerint a tanulás folyamatos fejlődést jelent, amely az oktatás és képzés valamennyi formáját magába foglalja. Formális, non-formális, és informális tanulásról egyaránt beszélhetünk. A tanulási folyamat színtere bárhol megvalósulhat [17]. Ezek a tanulási formák mind hozzáférhetőek a multikulturális társadalmakban, ahol az elméletre és a gyakorlatra épülő megközelítés is elismert [38]. Emellett az állandó tanulás, a fejlődés feltétele a munkavégzésnek [33].

Csoma (2009) szerint a tanulás, mint tevékenység személyközi kapcsolatok, interperszonális interakciók, és kommunikáció révén megy végbe, mely az információk egyén általi elsajátítását, és értelmezését foglalja magába. Ennek eredményeképpen a személyiség tartós változása következik be. Nahalka (2006) megfogalmazásában a tanulás folyamatos értelmezést kívánó és létrehozó emberi tevékenység. Olyan cselekvéssorozat, melynek a végén el tudunk végezni olyan feladatokat, amelyekre a tanulási folyamat elején még nem voltunk képesek. Ennek megfelelően a tanulás egy rendszerben végbemenő és hosszabb távon ható adaptív változás. A tanulás felfogható, egy olyan individuális tevékenységként, mely szociális közegben megy végbe. Ez igaz akkor is, ha spontán tanulásról beszélünk [8].

Super (1980) a tanulást egy olyan élethosszig tartó folyamatnak írja le. Nem csak a formális, iskolai tanulás jelenik meg az emberek életében, hanem munka során is folyamatosan új és új módszereket ismernek meg, új technikák, eszközök jelennek meg, melyek használatának megtanulása jobb, precízebb, gyorsabb munkavégzést eredményeznek. A Super által említett tanulás nem csupán a lexikális ismeretek gyarapítását jelenti, hanem a szociális tanulás folyamatát is magába foglalja. A szociális tanulás kisgyermekkorban elkezdődik, ekkor tanuljuk meg az alapvető viselkedési normákat, ahogy öregszünk, úgy ismerjük meg az új attitűdöket, hogyan kell az iskolában, munkahelyen, társaságban stb. viselkedni. Az elsajátított a viselkedési formák meghatározzák későbbi életünket, könnyebbé illetve nehezebbé tehetik a társadalomba való sikeres beilleszkedést [40]. 


\subsection{Felnőttoktatás, felnőttkori oktatás}

A felnőttkori oktatás és képzés ma még nem rendelkezik jól körülhatárolható fogalmi rendszerekkel. Széles körben értelmezik a különböző szakirodalmak. Durkó (1999) szerint a felnőttoktatás lényege, hogy a személyiség gazdagodjon, és differenciálódjon az új ismeretek, képességek, és tulajdonságok létrejöttével. A Felnőttoktatási kislexikon három különböző meghatározást ad a felnőtt nevelés értelmezésére. Az egyik megfogalmazás szerint olyan nevelési folyamatok összessége, amely során egy felnőtt továbbfejleszti a már meglévő készségeit, gazdagítja az ismereteit, tökéletesíti a szakmai tudását. Ez eltekint a tanulás tartalmától, szintjétől és módszereitől. A másik meghatározás szerint a felnőttképzést úgy értelmezhetjük, mint a permanens nevelés második továbbképző szakaszát, amely a felnőtt egyén személyiségének az egészére, szocializációjának minden területére törekszik hatni a nevelési hatásrendszerek különböző formáin keresztül. Végül a felnőttek nevelésével foglalkozó koncepció abból indul ki, hogy a felnőtt személyek az életmódjuktól, szociális körülményüktől, munkájuktól, és motiváltságuktól függően nevelhetők [7]. A felnőttképzésnek van egy viszonylag új irányzata, melyet munkahelyi tanulásként értelmeznek. Ez megvalósulhat munkahelyen vagy munkahely által biztosított szervezeti keretek között egyaránt [3].

A tanulmányban a felnőttkori tanulás fogalma alatt a KSH által adott definíciót alkalmazom, mely szerint azt a képzést kell érteni ez alatt, ahol a tanuló személy a magánéleti, munkahelyi vagy egyéb elfoglaltságai mellett a meglévő ismereteihez igazodóan iskolai oktatásban vesz részt [27]. A tudás megújítása, és megszerzése meghatározza az életút sikerességét, befolyással bír az életvitel kialakítására, valamint a személyiség formálódására. A felnőttként tanuló réteg számára a tanulás a művelődés és fejlődés természetes eszköze [31]. Míg korábban a gyermekkort határozta meg a tanulás és iskoláztatás, a felnőttkort pedig a munkavégzés, addig mára ez a határ elmosódni látszik. Sok esetben fedi egymást a tanulás és a munka, különös tekintettel a felsőoktatási tanulmányokra. Sokan ezt azzal magyarázzák, hogy a boldoguláshoz minél hamarabb kell munkatapasztalatot szerezni, és a munkaerő-piaci nehézségekre felkészülni [18].

A felnőttkorban végzett tanulás eredményessége több tényezőtől függ, mint például a motiváció, az öröklött tudás, vagy a tanulással kapcsolatos képességek [11]. Korunk meghatározó mozgatórugója a társadalom tudásközpontú múködése. Mind vállalati, mind egyéni szinten a tudás képzi a versenyképesség alapját. Erőforrásként, és áruként jelentkezik a piacon. A tudás elválaszthatatlan a tanulás fogalmától [10]. Az oktatásról való gondolkodásban új irányok, új paradigmák jelentek meg az elmúlt években külföldön és hazánkban egyaránt, melyek különös jelentőséggel bírhatnak a hagyományos egyetemi korosztálynál idősebb, úgynevezett felnőtt hallgatók oktatásában [20]. Vagyis, ma már elérhetőek a hallgatók számára olyan cselekvő tanuláson alapuló módszerek is, mint a finn Team Academy a Debreceni Egyetemen [2,15].

A felnőttkori tanulás okaként felfogható, hogy m már nem feltétlenül beszélhetünk élethosszig biztonságot nyújtó munkahelyekről, akár 5-7 szakmaváltásra is szükség lehet (Mohácsi, 2013). A jelenlegi gazdasági helyzetben, valamint az oktatás és a munka világa közötti kapcsolat miatt nagyon fontos, hogy milyen ismeretekkel rendelkeznek a végzett diákok a szakmájukkal, az elhelyezkedéssel kapcsolatban [35]. 


\subsection{Tanulási motiváció}

A motiváció hátterében nemtől, fajtól, kultúrától, és generációs hovatartozástól függetlenül egy egyszerű, mégis összetett dolog húzódik meg, miszerint az embereknek a pszichológiai szükségleteiket ki kell elégíteniük. Ezek a szükségletek Matkó - Takács (2017) szerint a visszacsatolás, a tudatosság, a felelősségvállalás, a független teljesítmény, a megalapozott célok, a kihívást jelentő feladatok és az igazságosság. Minden egyénnek pszichológiai igénye van az autonómiára, a kötődésre és a kompetenciára. Az emberek tanulásra születtek, céljuk a fejlődés, produktivitás, és az életük élvezése $[1,14]$.

A motivációt pszichológiai szempontból az emberi tevékenység ösztönzéseként foghatjuk fel, míg a tevékenység elvégzésére irányuló feladatokat motívumoknak nevezzük. A motiváltság egy belső tudatállapot, mely arra készteti az egyéneket, hogy valamilyen módon viselkedjenek, és cselekedeteket hajtsanak végre [37]. Juhász (2004) szerint a motiváció egy olyan érzelmi és tudati állapotot takar, amely a külső és belső hatásokra adott válasz, mely valamilyen viselkedési formában nyilvánul meg. Vizsgálati eredményei alapján jól meghatározhatóak és elkülöníthetőek a külső és belső tényezők, melyek a szükségletek tekintetében különösen érvényesek.

A tanulási motivációk tárgyalása során különbséget érdemes tenni a tartós, habituális és az aktuális motiváció, valamint az elsődleges és a másodlagos motiváció között [23]. Tóth (2007) extrinsic, vagyis külső motiváció és intrisic azaz belső motiváció megnevezésekkel él amikor az elsődleges és másodlagos felosztásról beszélünk. A szekunder azaz extrinsic motiváció a feladattól, a tevékenység tárgyától valamilyen, rendszerint független, külső indíték, mely lehet jutalom, dicséret, érdek, versengésben létrejövő önérvényesítés, vagy akár büntetéstől való félelem [25]. A motiváció másik típusa - amely mindenfajta tanulási tevékenységben alapvető -, a közvetlen, tárgyra irányuló, belső indíték (primer, intrinsic motiváció), amely érdeklődésben, kíváncsiságban, a probléma által okozott feszültségben jut kifejezésre. Habituális motivációról beszélünk az adott tárgy iránti általános érdeklődés esetében. Ez kedvet és elszántságot jelent bizonyos ismeretek megszerzésére, készségek elsajátítására, képességek fejlesztésére, vagyis bizonyos kompetenciák megszerzésére. A motivációnak ezt a fajtáját döntő mértékben a végcél mozgatja. Az aktuális motiváció arra vonatkozik, hogy az egyénben van általános vonzódás és készség egy bizonyos tudás együttes megszerzésére a képzés valamelyik részmozzanatában, azaz készen áll-e az együttműködésre, hajlandó-e erőfeszítések megtételére. Ennek megfelelőn primer motiváción azt értjük, hogy a tanulási cél fejt ki motiváló hatást, mely megfelel ebben az értelemben a habituális, valamint az intrisic motivációnak. Míg a szekunder motiváció esetében az éppen napirendre került téma, az előadó személye vagy a foglalkozás színessége, a felmerülő problémákban való érintettség miatt aktivizálja magát az egyén, azaz extrinsic, vagy aktuális tanulási motivációról beszélünk [23]. Azonban a belső motiváció aktiválódása esetén bármi, amit a központi cél érdekében tesz az egyén, azt a saját öröme érdekében végzi. Tanulás során távlati, tartós hatás csak a belső, érdeklődésre, kíváncsiságra, kutatásra keresésre ösztönző aktivitástól várható. Az önálló ismeretszerzésre irányuló orientáció, a megismerési motiváció a tanulás folyamán alakul ki [25].

A tanulásban való részvételi szándék okait Boshier (1982) hat fő faktorra bontotta. 
- Társas kapcsolatok keresése: ez a faktor azoknál az egyéneknél jelenik meg, akik a másokkal való együttdolgozás miatt vágynak a továbbtanulásra.

- Társas ösztönzés keresése: ez az ok azoknál jelenik meg, akik magánéleti problémákkal küzdenek, a tanulásban tudnak kiteljesedni, ezért csatlakoznak egy-egy tanulási folyamatba.

- Szakmai előrelépés: a biztos anyagi háttér és a stabil munkaviszony, valamint az előrelépés miatt képzi magát az egyén.

- Közösségi munka: a közösségi munka hatékonyabb elvégzése miatti tanulást jelenti.

- Külső elvárások: a magánéletből vagy a munkahelyi életből eredeztethető nyomás hatására tanulnak az egyének, önmegvalósítás helyett kényszernek érzik a tanulást.

- Tudásvágy: csak a saját tudás gyarapítása a cél, nem mérvadó, hogy a későbbiekben hasznosítható lesz-e a megszerzett ismeret.

Az OECD tanulásban való részvétel, arra való késztetésre irányuló vizsgálata alapján szintén hat tényezőt azonosítottak. Ezt a felmérést 18 országban végezték el, és azt vizsgálták, hogy mely tényezők játszanak szerepet abban, hogy a felnőtt társadalom visszaül az iskolapadba. A meghatározott tényezők a következők szerint írhatók le:

- munkáltató által megkövetelt szakmai képzések;

- személyes igény a „második esélyre”;

- munkabér és életszínvonal növelésének a lehetősége a plusz tudás birtokában;

- igény a nagyvállalati szinteken biztosított képesítésékre;

- migránsként a munkaerőpiacon való elhelyezkedés biztosítása tudásszerzéssel;

- megváltozott munkaképességűként speciális munkakör elérése [30].

A fent felsoroltakon túl kutatások bizonyítják, hogy a tanulásban, illetve a tanulói attitűd kialakulásában a korábbi tanulói évek alatt hozott döntések is szerepet játszanak. Azaz a tanuláshoz való viszony lényeges elemei közé sorolhatók az iskolai évek alatt szerzett tapasztalatok, élmények, valamint az otthonról hozott minta a tanulásra vonatkozóan [12].

A felnőttek és a fiatal, középiskolát végzett korosztály tanulási motivációi között eltéréseket fedezhetünk fel. Ez a különböző életkori célokból eredeztethetőek. A felnőttek esetében döntően a társadalom tagjait a külső motivációs „eszközök” vezérlik az iskolapadba való visszatérésre, amit (Tőzsér, 2014) munkája és eredményei is megfogalmaznak. A szerző a felnőtt tanulók oktatásban való részt vételét három meghatározó tényezőre bontja. Ezek a munkaerő piaci és karrier lehetőségek, a tudásfejlesztésre való törekvések, valamint a társas és közösségi hatások [42]. Magyar kutatások eredményei alapján a felnőttkori tanulás növeli a személyes komfortérzetet, amely 5 fő elemből tevődik össze:

- érzelmi komfortérzet, mely a pozitív érzelmeket (boldogság, öröm) tartalmazza, valamint a negatív érzelmek (szorongás, szomorúság) hiányát;

- élettel való elégedettség;

- vitalitás, életerő, aminek a hátterében fizikai aktivitás, egészséges életmód lehet; 
- önértékelés, olyan lelki erőforrás, ami önbecsülést ad, jövőbeli optimizmus, problémákhoz való pozitív hozzáállás jellemzi;

- egyén „pozitív működése”, amely magába foglalja a célokat, az elkötelezettséget, autonómiát, és kompetenciát [21].

A felnőttkori tanulás hátterében bármilyen ok is áll, fontos, hogy az egyén felelősséget vállaljon saját tanulásáért, és a gondolkodását, érzelmeit, cselekvéseit ennek megfelelően alakítsa. Alapvető eszköze lehet a személyeknek a metakogníció, vagyis a tanulásra ösztönző külső-belső tényezők rögzítése, a tanulási sajátosságokra történő koncentrálás, valamint az információszerzés [36].

\section{Módszertan}

A tanulmányban közölt eredmények három különböző felmérés eredményei közül kiválasztott, egy területre korlátoznak. A felmérések diplomadolgozat elkészítéséhez készültek, melyet Csege Gyula Szakigazgatás Szervező és Informatikus agrármérnök msc, Koroknai Dóra vezetés és szervezés ma, valamint Varga Dalma emberi erőforrás tanácsadó ma szakos hallgatókkal végeztünk. Minden esetben kérdőívet használtunk. A kérdőívek felépítését tekintve mind a három azonos volt abban, hogy két részből állt: az interjúazonosító adatokból, valamint a szakmai kérdésekből. Az interjúazonosító adatok esetében egységesen kérdezett a három kérdőív a megkérdezett korára, nemére, a továbbiakban attól függően, hogy az interjú alanyok kik voltak eltérések voltak. A tanulmány szempontjából ezen adatok relevánsak, így a továbbiakban az eltérésekre nem térek ki. A szakmai kérdések esetében is mutat a három kérdőív hasonló és eltérő pontokat. Mivel az eredmények közlése szempontjából a hasonlóság fontos így azt emelem ki, hogy mind a három alkalommal rákérdeztünk a válaszolók tanulási/továbbtanulási motivációjára, milyen okok határozzák meg a további tanulmányok folytatását. A megadott értékelendő szempontokat Likert skála segítségével kellett értékelniük a megkérdezetteknek. Mind a három esetben páratlan számú volt a skála, két felmérés esetében 5 fokozatú, míg egy felmérés esetében 7 fokozatú. A kapott válaszokat elsősorban leíró statisztikai módszerrel elemzem ebben a cikkben így átlagot, valamint szórást ismertetek.

\begin{tabular}{|l|c|c|c|}
\hline & $\begin{array}{c}1 . \\
\text { vizsgálat }\end{array}$ & 2. vizsgálat & 3. vizsgálat \\
\hline Megkérdezettek köre & $\begin{array}{c}\text { OKJ } \\
\text { képzés }\end{array}$ & mesterképzés & $\begin{array}{c}\text { végzős } \\
\text { középiskolások }\end{array}$ \\
\hline Kérdés típusa & 7 fokozatú & 5 fokozatú & 5 fokozatú \\
\hline Résztvevők száma & 20 & 63 & 123 \\
\hline $\begin{array}{l}\text { Értékelhető kérdőívek } \\
\text { száma }\end{array}$ & 20 & 48 & 118 \\
\hline Felmérés időpontja & 2015 & 2016 & 2016 \\
\hline Válaszadók életkora & $27-67$ év & $18-49$ év & $17-20$ év \\
\hline Nemek megoszlása & $95 \%$ férfi & $81 \%$ nő & $50-50 \%$ \\
\hline
\end{tabular}

1. táblázat: A vizsgálatok módszertanának, és legfontosabb elemeinek összefoglalása

(Forrás: Saját szerkesztés, 2017) 
A felmérésben résztvevők három csoportba sorolhatók. Az egyik csoportba tartoznak a magánvagyonőr $\mathrm{OKJ}$ képzésben résztvevők. Ebben a felmérésben 20 fő vett részt és a szakmai kérdésekre adott válaszok esetében 18 főnek voltak értékelhető adatai. A teljes adatszolgáltató sokaság nemi megoszlását tekintve elmondható, hogy 19 fó férfi és 1 fő nő volt, mely a képzés megnevezésével magyarázható, illetve ezen szakterületben átlagosnak tekinthető. Az életkor tekintetében 27 és 67 év közé sorolható a válaszadók. A felmérés 2015-ben készült.

A másik csoportba tartoznak a 2016-ban megkérdezett Debreceni Egyetem Vezetés és szervezés szakos I. és II. évfolyamos levelező tagozaton tanuló személyek. Ebben a felmérésben 48 fő adott választ a kérdésekre. A korcsoportokat tekintve elmondható, hogy a válaszadók 50\%-a 18-25 év közötti, 41,7\%-a 26-35 év közötti és a fennmaradó 8,3\% 36 évet betöltötte. A 18-25 év közöttiek feltételezhetően a 20-as évek fölöttiek, hiszen alapképzési diploma nélkül nem lehet mester szakra jelentkezni, azonban arra lehet következtetni, hogy az alapképzés megszerzése után sokan nem a nappali mesterképzésre jelentkeznek, hanem a levelező tagozatra, mely hátterében a munkatapasztalat megszerzése állhat. A válaszadók több mint 80\%- a aktív a munkaerőpiacon, így a válaszokban elsősorban a munka mellett vállalt tanulmányok jelennek meg. Ez egybevág egy nemrégiben végzett országos reprezentatív vizsgálat eredményével, miszerint az alapképzési diploma megszerzését követően dolgozni és mellette tanulni is akar a megkérdezettek 59\%-a [6]. Ezen túlmenően valamivel több, mint 10\% álláskereső, és 4-4 \% körül mozgott a GYES-en/GYED-en lévők, és a jelenleg máshol nappali képzésben résztvevők. A nemek tekintetében elmondható, hogy a válaszadók alig közel 19\%-a férfi. Az eredményeket a korcsoportok szerinti csoportosításban mutatom be.

A harmadik felmérés, mely szintén 2016-ban valósult meg, a tiszaújvárosi Eötvös József Gimnázium végzős évfolyamán készült. Összesen 123 fő töltötte ki a kérdőívet, akik közül 118-an válaszoltak úgy, hogy tovább szeretnének tanulni valamilyen képzési formában. A válaszolók közel fele- fele arányban voltak nők és férfiak. Korosztály szerint ebben a tanulmányban összefoglalóan a Z generációhoz tartozóként kezelem őket, hiszen a 13. évfolyam ellenére is 17-20 év közöttiek. A továbbtanulás valamely formáját 118-an jelöltek, akik közül 51,7\% egyetemre (Ba/BsC), 29,7\% egyetemre felsőoktatási szakképzésre (FOSZ), 5,1\% OKJ-ra, és 13,5\%-uk technikumra menne tovább.

\section{Eredmények}

Az eredmények fejezetben a három felmérés tanulási motivációkra vonatkozó eredményeit ismertetem, hasonlítom össze egymással, valamint a szakirodalmakban leírtakkal.

Az OKJ képzésben résztvevő személyek tanulási motivációjával összefüggő eredményeket az 1. ábrán szemléltetem. A kérdés úgy szol, hogy „Azért tanulok tovább......” 


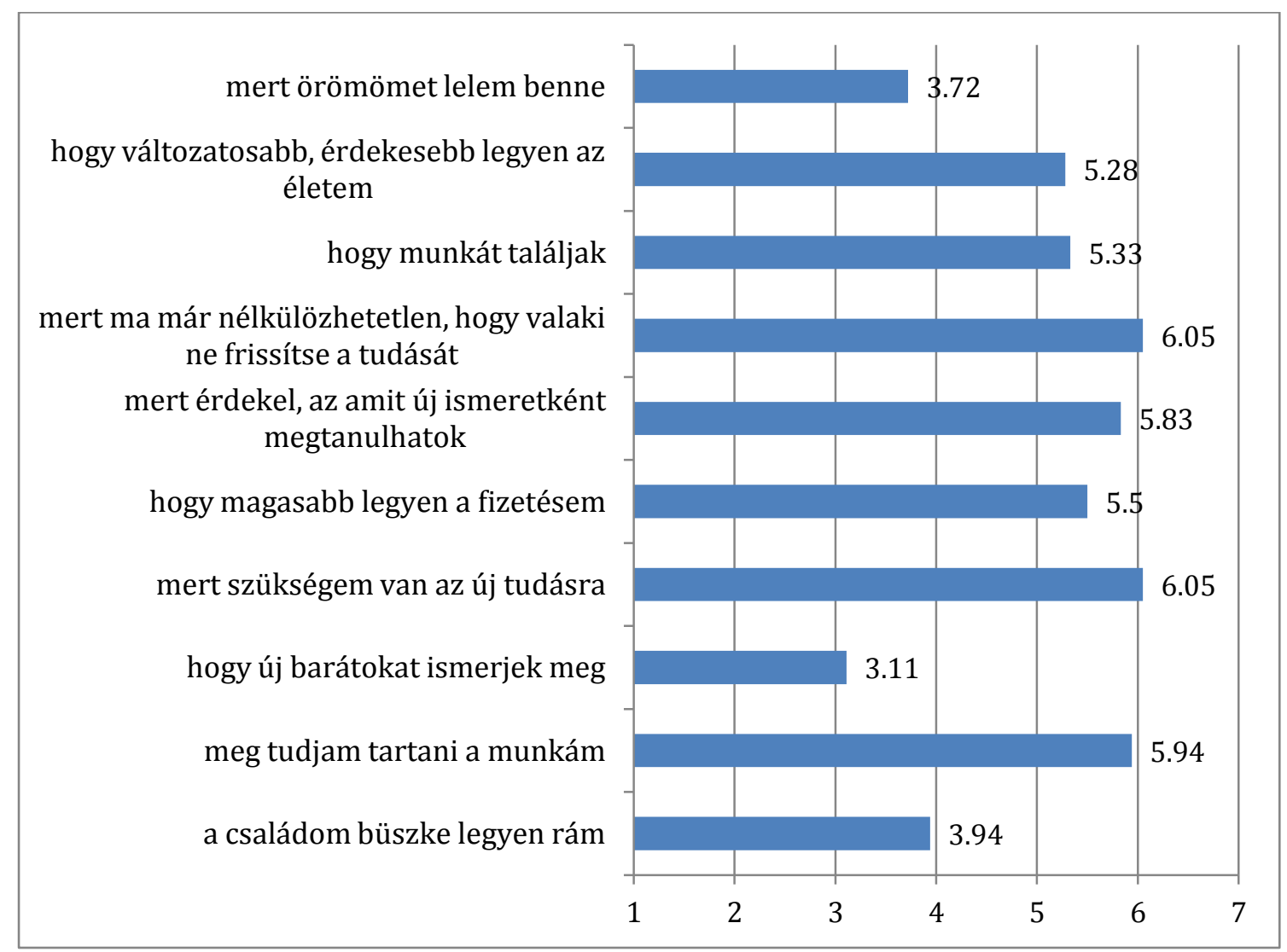

1. ábra: A magánvagyonőr OKJ képzésben résztvevők tanulási motivációja (N=20)

(Forrás: Saját szerkesztés Csege Gyula (2015) eredményei alapján, 2017)

$\mathrm{Az}$ ábra alapján elmondható, hogy válaszadók esetében kiemelkedő fontosságú a tudás frissítése $(6,05)$, a jelenlegi munka megtartása $(5,94)$, valamint az új tudás megszerzése $(5,83)$. A fontosak közé sorolható a magasabb fizetés elérése $(5,5)$, munka találása $(5,33)$, illetve hogy a válaszadó élete érdekesebb, változatosabb legyen $(5,28)$. Ezen túlmenően közepes fontosnak ítélték a család megítélését $(3,94)$, a saját öröm kifejeződését $(3,72)$, és az új kapcsolatok, új barátok megismerését $(3,11)$. Ezen eredmények alapján megállapítható, hogy a képzésben résztvevők elsősorban azért vannak jelen, hogy egy célt elérhessenek (munka találása/megtartása, fizetés) azaz a szekunder, habituális tanulási motiváció fontosabb, mint az aktuális motiváció. A család elismerése, barátok szerzése, saját öröm háttérbe szorul ebben az esetben.

A mester képzésben résztvevők által adott válaszok eredményeit a 2. ábrán mutatom be. Megállapítható, hogy az 5-ös skálán történő értékelés esetében is nagyon fontos, fontos és közepesen fontos értékelések születtek. Közepesen fontos a munkához kapcsolódó új ismeretek megszerzése, a munkahelyi stabilitás, a sikeresség, vagy a vezetői pozíció elérése. És összességében legkevésbé fontosnak, de még mindig az inkább fontos kategóriába sorolható a munkahelyi előrelépés lehetősége. Korosztályok szerint, ha elemezzük az eredményeket, akkor némi eltérés mutatkozik. A csoportok átlagai közel azonosak a széleskörű tájékozottság, valamint a magasabb jövedelem esetében, viszont az eltérő, melyik korcsoporthoz tartoznak az egyes átlagértékek. A magasabb jövedelem a 18-25 év közöttiek számára a legfontosabb (4,75), a 26-35 év közöttiek számára ez 4,4 átlagértékkel jelenik meg, míg csupán 4-esre értékelte a 36-49-es korosztály. Míg a széleskörű tájékozottság esetében azt 
látjuk, hogy a legfontosabb 4,71 értékkel a 36-49 korcsoportba tartozók számára, a 18-25 év közöttiek 4,4-re értékelték, és a 26-35 év közöttiek értékelték a legalacsonyabb, 4-es értékkel ezt a tényezőt. Maga a tanulás fontossága az egyes korcsoportok megítélése alapján nem mutat nagy eltérést. Bár a legmagasabb átlagértékkel a 18-25 év közöttiek értékelték $(4,54)$ és a másik két korcsoport hasonlóan vélekedett a maguk 4 és 4,05 átlagukkal. Érdekes tény, hogy a széleskörü tájékozottság fontos tényező mind a három csoport számára, viszont az új ismeretek megszerzése a munkavégzéshez már a két szélső csoport esetében nem olyan fontos, mint a 26-35 év közöttiek számára. Vélhetően ez azzal magyarázható, hogy a fiatalabbak még nem feltétlenül dolgoznak, illetve GYES/GYED mellett tanulnak, míg a 36-49 év közöttiek, annak ellenére, hogy a széleskörű tudás fontos ez kevésbé, a formai tanulásnál talán életszerübbnek gondolják az informális tanulást, amikor egymástól, és a munkahelyen vagy magánéletben kialakuló szituációkból vonnak le következtetéseket, és megállapításokat.

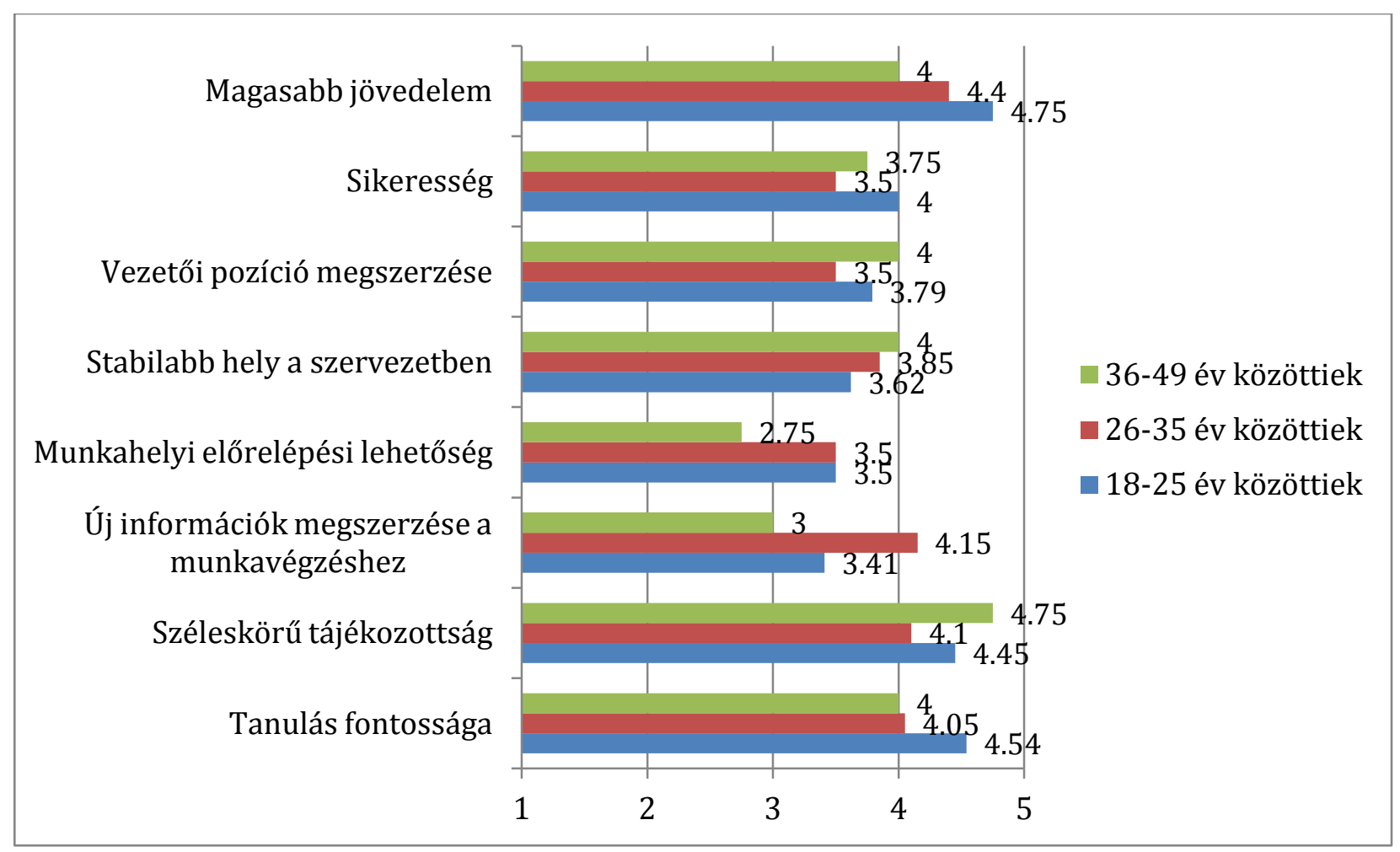

2. ábra: A vezetés és szervezés Ma képzésben résztvevő́k tanulási motivációja (N=48)

(Forrás: Saját szerkesztés Koroknai Dóra (2016) eredményei alapján, 2017)

A munkahelyi előrelépésének lehetőségét közepesen, vagy inkább nem fontosnak ítélték a válaszadók. A két fiatalabb csoport még 3,5 átlagot adott erre a tényezőre, míg a 36-49 korosztály már átlagosan 2,75-re. Ebből arra következtetni, hogy nem azonosítják a mesterdiplomát az előrelépéssel. Ezzel szemben a pozíció megtartásához már jobban kötik a diploma megszerzését, mivel ez a motivációs tényező minden csoportban magasabb átlagértékeket kapott. Az egyetemi továbbtanulás ennek megfelelően elsősorban biztosítékot jelenthet az egyének számára, inkább a saját pozíció megtartásának függvénye, mint az előrelépésnek, hiszen egyre inkább elvárás, és nem előny, ha valaki mesterfokozatú diplomával rendelkezik. A munkahely megtartásához hasonló átlagértékeket kapott a sikeresség, és a vezetői pozíció megszerzése, és a korosztályok közötti megítélésben sem fedezhető fel 
jelentős eltérés. Ezen tényezők értékelése alapján arra lehet következtetni, hogy a célok elérése, a munkahelyi hierarchiában történő előrelépés fontos motivációs tényező mind a három csoport számára. Emellett a megkérdezettek véleménye alapján a vezetői pozíció megszerzésének függvénye a mester diploma megszerzése. A munkahelyi szférában elért sikeresség, és a biztonságos anyagi helyzet megteremtése jelentősen ösztönzi a korosztályokat továbbtanulásra. A 26-35 évesek csoport inkább a jövedelemszerzést, a jólét megteremtését, és az anyagi függetlenség megteremtését vélik fő motivációs elvnek. Fontos számukra, hogy stabilizálják a meglévő helyüket a szervezetüknél. Továbbá kimagaslóan jelentkezik a magasabb fizetés, mint a képzéssel elérni kívánt cél. A 18-25 év közöttiek átlagos eredményei viszont egy az eddigi csoportoktól teljesen eltérő képet mutatnak. Bár a munkahelyi stabilitás, és az előrelépés is nagyon fontos számukra, mégis sokkal inkább az anyagi háttér kerül a középpontba. Az egyik legnagyobb céljuk, hogy sikeresek legyenek a munkájukban, amely magával vonja azt a tényt is, hogy kiemelkedő fizetést kapnak. Az anyagi háttér és a siker elérésének hajtása a két fiatalabb korcsoportban az életkori sajátosságokból is fakadhat, hiszen a pályájuk és a felnőtt életük elején állnak még, amikor az elsődleges cél a szülőktől történő függetlenedés, és a saját lábon való megállás.

Összefoglalva az eredményeket megállapítható, hogy a teljes mintát nézve a belső motivációs tényezőknek tekinthető tanulás fontossága, új ismeretek megszerzése fontos, és egy külső tényező jelenik meg hasonlóképpen a magasabb jövedelem. És a további tényezők, melyek a cél elérését, a habituális tanuláshoz tartoznak már a fontos, és közepesen fontos tényezők közé sorolhatók. Hasonló eredményre jutott Gergely -Nagy (2015) a továbbtanulással kapcsolatos motivációt vizsgálva egyetemisták körében, ugyanis megállapították, hogy a későbbi anyagi függetlenség lehetőségét és a céljaik megvalósítását remélik a megkérdezett hallgatók az egyetem elvégzésétől.

A középiskolások körében végzett felmérés során, a dákok által értékelendő szempontok sok tekintetben mutatnak hasonlóságot az OKJ képzésben résztvevők felmérésnél használt tényezőkkel. Az eredményeket a 3. ábrán szemléltetem. Az ábra alapján megállapítható, hogy az egyes tényezők átlagaiban jelentős eltérések mutatkoznak. A legfontosabb tényezőknek ítélték a diákok a későbbi anyagi függetlenség megteremtését $(4,45)$, a későbbi könnyebb munka találását $(4,4)$, a céljaik megvalósításának lehetőségét $(4,38)$, valamint a későbbi vezető pozícióba kerülés lehetőségét $(4,05)$. A fontos tényezők közé sorolták a biztos egzisztencia megteremtését $(3,98)$, és a saját képességek fejlesztését, a tudás növelését $(3,89)$. 


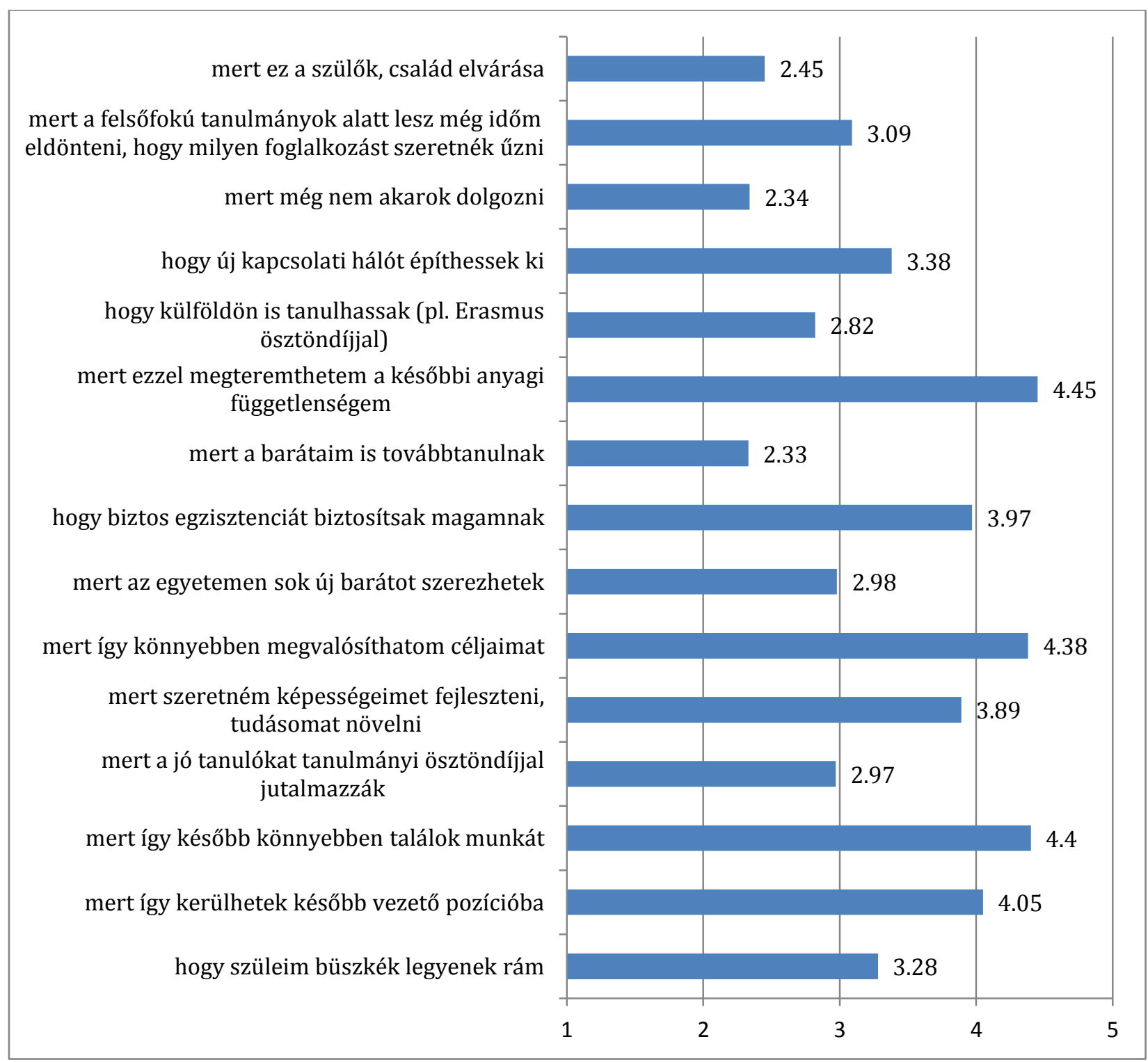

3. ábra: A középiskolában végzős diákok továbbtanulási motivációja (N=118)

(Forrás: Saját szerkesztés Varga Dalma (2016) eredményei alapján, 2017)

Közepesen fontosnak ítélték az új kapcsolati háló megteremtését $(3,38)$, a szülők büszkeségét $(3,28)$, azt hogy a tovább tanulás időt biztosít arra, hogy kitalálják, mivel akarnak foglalkozni $(3,09)$, az új barátok találását $(2,98)$, az ösztöndíjak megszerzését $(2,97)$, valamint a külföldön történő tanulás lehetőségét $(2,82)$. Egyértelmúen a végcél mozgatja még őket, azaz a habituális motiváció magas az esetükben.

Kevéssé fontos számukra a szülők, család elvárása (2,45), a még nem akar dolgozni $(2,34)$ barátok továbbtanulása $(2,33)$. A kapott eredmények szórását tekintve elmondható, hogy összességében 1,16 és 1,63 közötti értéket vettek fel. A későbbi könnyebb munka találása tényező esetében volt a legalacsonyabb a szórás $(1,16)$, mely arra enged következtetni, hogy a diákok közel azonosan vélekednek arról, hogy a munkaerőpiacon történő boldoguláshoz szükséges valamilyen végzettség megszerzése. Melyet a munkaadók oldaláról olyan formában erősíthető meg, hogy munkakörtől függ a 
diploma előny vagy sem [22]. A legmagasabb a szülők elvárása tényezőnél volt $(1,63)$. Ebből arra lehet következtetni, hogy annak ellenére, hogy az átlag alapján kevéssé fontos, mégis jelentős számban vannak, akik számára meghatározó tényező a továbbtanulásban a család által megfogalmazott elvárás. Az ábra alapján fontos megemlíteni azt a tényt, hogy a válaszadó diákok különbséget tettek a fontosságot illetően a már meglévő barátok továbbtanulása, az új barátok szerzésének lehetősége és a kapcsolati háló kialakításának lehetősége között. Ezek alapján elmondható, hogy a barátságot nem azonosítják a pusztán ismeretséggel, melyet a jövőbeli célok eléréséhez tarthatnak szükségesnek. Kevéssé a barátkozást, mint inkább ismeretségek szerzését látják a továbbtanulásban. Összességében ebben a csoportban végzett felmérések azt mutatják, hogy a külső, a célok elérésének fontossága erős motiváció a számukra, és még kevéssé fontosak a belső hajtóerők, az intrisic motivációk, mint a család, barátok.

\section{Következtetések, javaslatok}

A három felmérés alapján több következtetés is levonható, amiket óvatosan kell kezelni, és mindenképpen további vizsgálatokat igényel. A tanulási motiváció feltárása az egyes képzésekben, illetve az egyes generációkban az oktatással foglalkozók számára segítség lehet, hiszen ennek ismeretében nagyobb teljesítményre lehet sarkallni a tanulókat a megfelelő eszközök megtalálásával. Az OKJ képzésben résztvevő, valamint a középiskolában végzős évfolyamba járó megkérdezettek esetében egyértelműen megállapítható, hogy elsősorban a külső tényezők vannak befolyással a tanulási motivációjukra, szemben mesterképzésben résztvevőkkel, ahol a legfontosabbak közé két belső és csupán egy külső tényező sorolható.

Összességében a felmérések alapján elmondható, hogy a megkérdezettek elsősorban valamilyen kitűzött cél elérése érdekében tanul tovább valamilyen formában, nem pedig a saját örömére, vagy a tudás iránti vágya hajtja az iskolapadba. Így az eddigi eredmények azt mutatják, hogy az egyes képzési szinteken nem tudunk különbséget tenni, hogy aktuális vagy habituális inkább a motiváció. Bár vannak tényezők, amelyeknek a megítélésében, annak fontosságában különbségek mutatkoznak.

\section{Hivatkozások}

[1] Andrea, Matkó - Tímea, Takács (2017): Examination of the relationship between organizational culture and motivation, INTERNATIONAL REVIEW OF APPLIED SCIENCES AND ENGINEERING, Volume 8, Issue 1 (megjelenés alatt)

[2] Árváné Ványi Georgina- Katonáné Kovács Judit- Gál Tímea- Popovics Péter: Vállalkozói képzés a 21. században a felsőoktatásban - lehetőségek, módszerek, jó gyakorlatok. Múszaki és Menedzsment Tudományi Közlemények 1.:(1.) Paper 1. 14 p.

[3] Berde Csaba - Móré Mariann (2014): A munkavállalói tudás hasznosításának új lehetősége felsőoktatási keretek között. Vezetéstudomány 45:(11) pp. 44-54.

[4] Boshier, Roger (1982): The Education Participation Scale. Learning Press, Vancouver 
[5] Csege Gyula (2015): A tanulói motiváció vizsgálata a magánvagyonőrök képzése során. Diplomadolgozat. DE GTK. Debrecen, 83.p.

[6] Csehné Papp Imola (2016): Elvárások és realitások a munka világában. Taylor Gazdálkodás és Szervezéstudományi folyóirat. Virtuális Intézet Közép-Európa Kutatására Közleményei. VIII. évf. 2. sz. No 23. Szeged. pp 5-10.

[7] Csiby Sándor (1987, szerk.): Felnőttoktatási kislexikon, Kossuth Könyvkiadó, Budapest, 5859. p.

[8] Csoma Gyula (2009): A tanulás értelmezése és funkciói. http://ofi.hu/tudastar/tanulaskora/tanulas-ertelmezese Letöltés dátuma: 2016.07.03.

[9] D. Molnár Éva (2010): A tanulás értelmezése a 21. században, Iskolakultúra, 11. sz., 3-16. p.

[10] Dobák Miklós - Ferincz Adrienn - Hortoványi Lilla (2014): A munkahelyi tanulás elősegítésének változásvezetési szempontjai, Magyar Tudomány, 175. évf. 12. sz., 14581466. p.

[11] Durkó Mátyás (1999): Andragógia: A felnőttnevelés és közművelődés új útjai, Magyar Művelődési Intézet, Budapest

[12] Engler Ágnes (2013): Az élethosszig tartó tanulás gender- szempontú megközelítése, Iskolakultúra, 23. évf. 2. sz., 3-11. p.

[13] Európai Bizottság (2000): Memorandum az élethosszig tartó tanulásról. Brüsszel, 2000. október 30. SEC(2000) 1832. pp 26.

[14] Fowler, Susan (2014): Why Motivating People Doesn't Work. And What Does The New Science of Leading, Energizing, and Engaging, San Francisco, Berrett-Koehler Publishers Inc.

[15] Gál Tímea - Katonáné Kovács Judit - Popovics Péter- Árváné Ványi Georgina (2016) Evolution of an innovative business education model from Finland in different European countries. In: L Gómez Chova, A López Martínez, I Candel Torres (szerk.) Proceedings of 9th International Conference of Education, Research and Innovation. Konferencia helye, ideje: Sevilla, Spanyolország, 2016.11.14-2016.11.16. Seville: International Association of Technology, Education and Development (IATED), pp. 3455-3464.

[16] Gergely Éva- Nagy Richárd (2015): Gazdasági szakos hallgatók tanulási motivációjának és személyes kompetenciáinak vizsgálata. KÖZÉP-EURÓPAI KÖZLEMÉNYEK VIII. évfolyam:(4. szám, No.31.) pp. 197-205.

[17] Hinzen, Heribert (2012): Towards Lifelong Learning for All. in.: Németh Balázs (szerk.) Andragógiai kutatások és fejlesztések. Tisztelgő tanulmánykötet Koltai Dénes tudományszervezői és kutatói munkássága előtt. Pécs: PTE FEEK. (ISBN:978-963-642461-9) 
[18] Horváth Kitti - Kósa Rita Diána - Makai Vivien - Nagy Péter - Oláh Kornélia - Oláh Tímea Oláh-Pucsok Eszter - Szeder Dóra Valéria - Timkó Anikó (2014): Tanulás melletti munkavállalás a Debreceni Egyetemen, Metszetek, 3. évf. 1. sz., 328-344. p.

[19] Juhász Csilla (2009): Motiváció a mezőgazdaságban. Debreceni álláspont. Magyar Mezőgazdaság: A Magyar Mezőgazdasági Művelődési Társaság Lapja 64:(33) Pp. 5-7.

[20] Keczer Gabriella (2016): Felnőtthallgató-barát oktatási paradigmák. Taylor Gazdálkodás és Szervezéstudományi folyóirat. Virtuális Intézet Közép-Európa Kutatására Közleményei. VIII. évf. 3. sz. No 24. Szeged. pp 120-130.

[21] Kispálné Horváth Mária - Mátrai Zsuzsa (2015): Felnőttkori tanulás és komfortérzet, Neveléstudomány: oktatás - kutatás - innováció 3. évf. 4. sz., 58-70. p.

[22] Kiss Zsuzsanna- Máté Domicián (2016): Frissdiplomások foglalkoztathatósága vállalati szemszögből, avagy mit preferálnak a munkaadók? Taylor Gazdálkodás - és Szervezéstudományi folyóirat. Virtuális Intézet Közép-Európa Kutatására Közleményei. VIII. évf. 2. sz. No 23. Szeged. pp 11-18.

[23] Koltai Dénes - Zrinszky László (2008): A tanulás az andragógiai pszichológiában. Andragógiai ismeretek. Tanár-továbbképzési Füzetek. Nemzeti Szakképzési és Felnőttképzési Intézet. 20-25p

[24] Koroknai Dóra (2016): Felnőttkori tanulás motivációja. Diplomadolgozat. DE GTK. Debrecen, 84.p.

[25] Kósáné Ormai Vera (1998): A mi iskolánk: Neveléspszichológiai módszerek az iskola belső értékelésében, Budapest, Iskolafejlesztési Alapítvány (ISBN 9638323 24 8), 103-104. p

[26] Kőmíves Péter Miklós - Dajnoki Krisztina (2016): Élethosszig tartó tanulás: híd a munkaerő-piac és a felsőoktatás között. Taylor Gazdálkodás - és Szervezéstudományi folyóirat. Virtuális Intézet Közép-Európa Kutatására Közleményei. VIII. évf. 4. sz. No 25. Szeged. pp 86-94.

[27] $\mathrm{KSH}$

(2016):

Felnőttoktatás,

felnőttképzés https://www.ksh.hu/docs/hun/xftp/stattukor/felnottoktatas13.pdf Letöltés ideje: 2016.07.03.

[28] Lappints Árpád (2002): Tanuláspedagógia. A tanulás tanításának alapjai. Comenius, Pécs

[29] Metzig Werner - Schuster Martin (2003): Tanuljunk meg tanulni! A tanulási stratégiák hatékony alkalmazásának módszerei, Budapest, Medicina Könyvkiadó Rt. (ISBN 963242797 1), 42-81. p.

[30] Mihály Ildikó (2003): Felnőttek tanulása - elméleti és gyakorlati tapasztalatok. Új Pedagógiai Szemle, 10. sz., 120-132 p.

[31] Mócz Dóra (2010): Az élethosszig tartó tanulás jelentősége a 40-50 éves korosztály életútjában, Iskolakultúra, 2010. (20. évf.) 4. sz. melléklet, 3-15 p. 
[32] Mohácsi Márta (2013): Az oktatás és a munkaerőpiac sajátosságainak elemzése, regionális jellemzői. Virtuális Intézet Közép-Európa Kutatására Közleményei. 12-13. sz. pp. 15-19.

[33] Móré Mariann - Szabados György Norbert (2012): A felnőttképzésben szerzett munkatapasztalatból származó tudás elismertetése a felsőoktatásban ACTA ANDRAGOGIAE ET CULTURAE 24: pp. 352-358.

[34] Nahalka István (2006): Mi a tanulás? In.: A gyakorlati pedagógia néhány alapkérdése 3. kötet, Hatékony tanulás (szerk: Nahalka I.), Budapest, Bölcsész Konzorcium (ISBN 963 972404 1), 9-19. p.

[35] Oláh Judit - Hutóczki Renáta (2012): A Debreceni Egyetem emberi erőforrás tanácsadó szakán végzett hallgatók pályakezdők munkaerőpiaci esélyei Magyarországon. Közgazdász Fórum, XV. évf. 107. sz. 2012/4, 27-40.p.

[36] Réthy Endréné (2003): Motiváció, tanulás, tanítás: Miért tanulunk jól vagy rosszul? Budapest, Nemzeti Tankönyvkiadó (ISBN 963194466 2)

[37] Roóz József - Heidrich Balázs (2013): Vállalati gazdaságtan és menedzsment alapjai. http://www.tankonyvtar.hu/hu/tartalom/tamop412A/0007_c1_1054_1055_1057_vallala tigazdtan_scorm/adatok.html Letöltés dátuma: 2016.06.27.

[38] Rubenson, Kjell (2010): Adult education overview. In Peterson, Penelope - Baker, Eva McGaw, Barry (eds): International Encyclopedia of Education. Third edition. Elsevier Academic Press, 1.-11. p.

[39] Super, E. Donald (1980): A Life-Span, Life-Space Approach to Career Development. Journal of Vocational Behaviour 16, 282-298 p.

[40] Super, E. Donald (1990). A life-span, life space approach to career development. In D. Brown, L. Brooks, \& Associates, Career choice and development 2nd ed., San Francisco: Jossey-Bass. pp. 197-261.

[41] Tóth László (2007): Pszichológia a tanításban, Budapest. Pedellus 158.159.719.p

[42] Tőzsér Zoltán (2014): Részvételi célok és akadályok a felnőtt és idős hallgatók körében, Iskolakultúra 24. évf. 2. sz., 34- 43. p.

[43] Varga Dalma (2016): A Z generáció továbbtanulási motivációi. Diplomadolgozat. DE GTK. Debrecen, 68.p. 